\title{
The Learning Design and Student's Response to Physics Online Learning In Rural School of Indonesia
}

\author{
Dwi Sulisworo, Dian A. Kusumaningtyas, Trikinasih Handayani, Eko Nursulistiyo
}

\begin{abstract}
The implementation of e-learning on science learning in Indonesia is a critical issue, especially in the context of implementing a curriculum oriented towards the competency of students in today's digital era. The problem faced by educators is in the social presence; in how to manage effective interaction between teachers-students and students-students. This study aims to innovate e-learning which is Edmodo as a learning management system (LMS) that is suitable for science learning requirements (Light and Optics) in junior high school students. The research method used was a mix of qualitative and quantitative methods. The process of developing learning design was arranged through focus group discussion approach (which involves LMS experts, learning evaluation experts, learning strategists, physicists, and teachers) iteratively to obtain learning designs embedded in the Edmodo. The sound learning design was then tested in a small group consisting of eighth-grade students. Responses were measured using a USE questionnaire containing four aspects, i.e., usefulness, ease of use, ease of learning, and satisfaction aspects. The results of the trial in the small group will indicate that LMS and learning activities carried out meet student learning needs. These results provide optimism that mobile learning with appropriate strategies can meet the learning needs of science, including in schools that have never used this technology before.
\end{abstract}

Keywords-e-learning, learning design, learning innovation, learning management system, learning strategy, mobile learning, social presence.

\section{INTRODUCTION}

The issue of using e-learning in learning in Indonesia is a crucial issue at this time. There are opinions among educators regarding the use of this technology in learning. On the one hand, educators consider that the effectiveness of e-learning is low in encouraging student learning achievement. This assumption is based on the belief that the best learning can only occur in learning in the classroom where the teacher meets directly with students.

On the other hand, educators see that e-learning is a new way or approach in learning that is in line with changes in the learning environment and also the characteristics of current students. This new learning environment is related to the concept of the connection as a part of learning theories in this

Revised Manuscript Received on November 08, 2019.

D. Sulisworo is Professor in Educational Technology. He is now with Physics Education Department, Graduate Program, Ahmad Dahlan University, Indonesia (email: sulisworo@gmail.com)

D.A. Kusumaningtyas and E. Nursulistiyo are with Physics Education Department, Undergraduate Program, Ahmad Dahlan University, Indonesia.

T. Handayani is with Biology Education Department, Undergraduate Program, Ahmad Dahlan University, Indonesia. era [1],[2]. This belief is based on that the development of information technology that influences in various fields also affects the behavior of people (students) in how to obtain knowledge [3]. The behavioral characteristics of these students who tend to be comfortable with the virtual community need to be facilitated and supported in different ways in the learning process.

The results of research on e-learning generally show that learning in this way provides opportunities in many aspects such as student competency, learning flexibility, and diversity of learning resources [4]. By using a constructivist perspective, e-learning makes it possible to position students as learning centers. Teachers need to try new roles in learning. In learning, the availability of well-managed learning materials and the high social presence will determine the student's learning success [5]-[7]. However, the interaction between teachers and students in e-learning are still challenging that needs special attention. Teacher and student interactions in both direct learning and e-learning will determine the success of the learning process [8],[9]. Some studies try to be able to develop interactions in e-learning with a variety of strategies. Until this time, there is no specific strategy to follow by educators to be successful in managing online learning [10]. Selection of suitable learning strategies in e-learning will enable the achievement of learning objectives [11], and it highly depends on the learning environment faced by the teacher.

In online learning, the high cognitive intensity level does not guarantee the learning performance especially in the effort to encourage the higher order thinking skills; but social presence could do so [5],[12] and could be used as a learning success predictor [2][13]. Different from face-to-face learning with physical attendance, it does not happen in online education. Some researches showed that one of the factors causing students to not sustain in the online learning was the teacher's social presence in the online space [14],[15]; students in online learning sometimes feel emotionally less-connected with friends and the teacher [16]. Therefore, research on how to increase social presence is challenging research in nowadays education.

One of the excellent interaction strategies in online learning is less-structured communication [8] which is providing a thread in the discussion following the psychological development [17]. This strategy will increase the student's learning satisfaction. However, in online learning, the teacher needs to have an awareness of 
controlling learning. High learning control by the teacher could increase cognitive presence, but it will decrease social presence that affects a student's critical thinking skill [18] and student's engagement [19]. The social presence will also positively increase when the teacher builds interaction that encourages attitudes of respect, positive, motivate, punctual, free-flowing and repetitive [17],[20].

This strategy will then be implemented in managing to learn through the chosen learning management system. Thus, it should be noted how to integrate the approach with the features that exist in LMS. The selection of a simple LMS, but sufficient is essential. Therefore, the implementation of the strategy is fit to the level of mastery of IT of the teachers and students. The results of the research before showed that from various existing LMS (for example Moodle, Google Classroom, and Socrative), the LMS that was relatively appropriate for teachers in Indonesia was Edmodo [21],[22]. Features with a simple one are the advantages of this LMS. From the discussion, the research question is how to design learning activities with specific strategies that can facilitate optimum learning interactions.

\section{METHOD}

\section{A. Research Context}

This research is a mix of qualitative and quantitative research. Fig. 1 shows the stages of research. There are three main stages: preparing the preliminary design, attaching activities and teaching materials into the LMS (Learning Management System), validating the designs in the LMS by expert's judgment and conducting the trial of learning strategy design small groups.

\section{B. Focus Group Discussion}

The FGD (Focus Group Discussion) was conducted at the first stage to determine the initial design of learning. In the FGD, there were five experts involved, namely LMS expert, learning evaluation expert, learning strategy expert, physics expert, and physics teacher. The primary purpose of the FGD was to decide what kind of learning design would be the most suitable for Light and Optics subject for eighth-grade students held in m-learning using LMS (Edmodo). During the FGD, it is expected that the participants can contribute appropriate strategies through discussions that will converge on the initial learning design explaining the learning strategy criteria. The experts would use these criteria as the standard on giving judgment of the system validation. The output from the FGD is as shown in the following Table I.

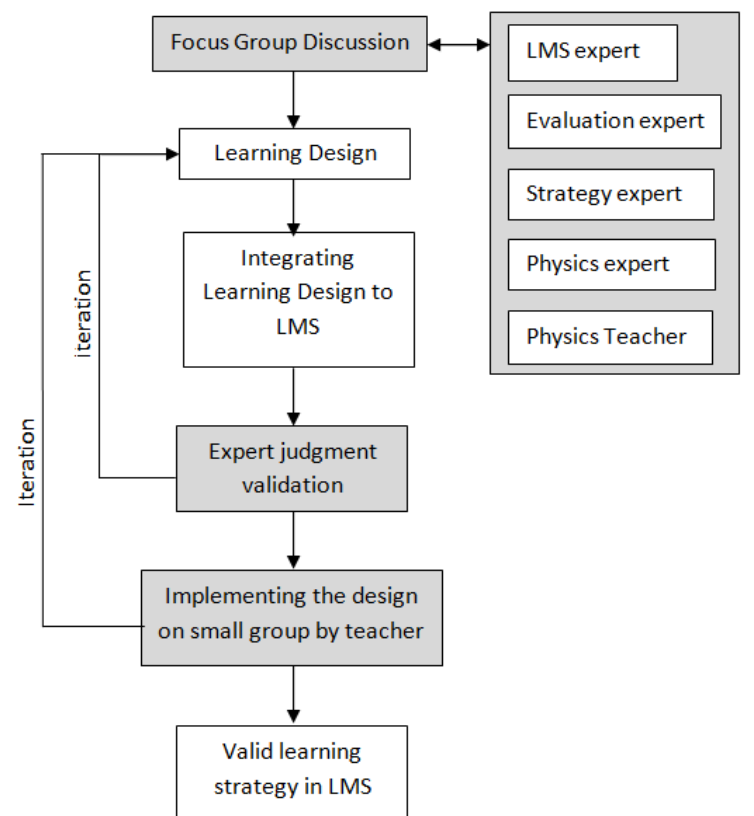

Fig. 1. The research procedure

Clear responsibilities for experts was defined to ensure that the learning design criteria were developed in accordance with the expectations of learning outcomes. Experts provided input and suggestions in accordance with their respective roles simultaneously and iteratively during the focus group discussion process.

\begin{tabular}{|c|c|c|}
\hline \multicolumn{3}{|c|}{ TABLE I: THE EXPERT'S RESPONSIBILITIES } \\
\hline No & Experts & Responsibilities \\
\hline 1 & $\begin{array}{l}\text { LMS } \\
\text { expert }\end{array}$ & $\begin{array}{l}\text { Decide the available features of the LMS (i.e., } \\
\text { Edmodo) } \\
\text { Prepare the learning sequence on the LMS }\end{array}$ \\
\hline 2 & $\begin{array}{c}\text { Evaluatio } \\
\text { n expert }\end{array}$ & $\begin{array}{c}\text { Identify the method to measure student } \\
\text { competencies } \\
\text { Design the learning evaluation instrument }\end{array}$ \\
\hline 3 & $\begin{array}{c}\text { Strategy } \\
\text { expert }\end{array}$ & $\begin{array}{l}\text { Select a suitable strategy for maintaining } \\
\text { interaction during online learning } \\
\text { Decide the learning procedure }\end{array}$ \\
\hline 4 & $\begin{array}{c}\text { Physics } \\
\text { expert }\end{array}$ & $\begin{array}{c}\text { Check the learning content to avoid the } \\
\text { misconception } \\
\text { Provide the learning material }\end{array}$ \\
\hline 5 & $\begin{array}{l}\text { Physics } \\
\text { teacher }\end{array}$ & $\begin{array}{l}\text { Synchronize the learning outcome to the standard } \\
\text { curriculum } \\
\text { Identify the congruence between online learning } \\
\text { and classroom learning }\end{array}$ \\
\hline
\end{tabular}

\section{Expert Judgment Validation}

The results of the learning design were validated using an expert judgment approach. Expert judgment was used to ensure that the characteristics of the learning design have been embedded to the LMS according to the learning needs or requirement (characteristics of student's interaction, learning competencies, learning strategies, features used). Expert judgment was iterative activity until the appropriate learning design structure was found. In this process, the initial design was obtained from the FGD.

Furthermore, this design was sent to each expert to be validated. If it were not suitable, it would be revised and returned to the related expert. This iteration was carried out until the appropriate design was obtained. The final result of this stage was valid for the learning design with Edmodo. This iteration process is similar to the Delphi method in expert judgment decision making. 


\section{The trial in the small group of students}

Sound learning designs will then be tested in small groups. The students involved in this trial were 33 of eighth-grade students at a school in Bantul, Indonesia. Before students engaged in learning with this design; the teacher first socialized students about Edmodo for learning. The teacher taught from creating an account and interacting using the menu in the LMS. This activity was carried out to ensure that students could communicate in the LMS. This study was carried out within three meeting days (@3 hours per day). The first day was associated with the introduction of Edmodo and its menu. The second day was related to how to interact in online learning. The third day was related to evaluating online learning.

After students understood the interaction in m-learning, then the reliable learning design results were tested on students with a duration of time as specified in the physics learning standards on the topic of Light and Optics. At this stage of the trial, all activities under the design would be carried out, that was, from students joining in learning to evaluate learning. The response of students in learning according to valid configurations was measured using a USE questionnaire [23]. The scale used was a Likert scale from 1 to 4; where 1 means strongly disagree, 2 means disagree, 3 means agree, and 4 means strongly agree. Aspects measured by this questionnaire include usefulness ( 8 items), ease of use (11 items), ease of learning (4 items), and satisfaction (7 items). The results of this questionnaire would be analyzed using descriptive statistics to explain the level of student acceptance in the learning design. Some suggestions for improvements in student responses will form the basis for revisions to learning designs; as revision process iteration. After this iteration, the sound learning design was found and would be used in comprehensive schools.

\section{RESULT AND DISCUSSION}

\section{A. Competencies and Learning Outcome Indicators}

The online learning is one of the learning modes that are also developed for high schools in Indonesia. In science learning at junior high school, for materials of Light and Optics, Table II shows the core competency and the leading competency indicators according to the national curriculum.

From Table II, it seems that indicators developed for eighth-grade students are indicators that have orientation on higher order thinking skills. The issues about HOTS have been an essential part of the national curriculum in Indonesia with the expectations of a better education. In line with the spirit of educational equality in Indonesia, online learning tries to integrate learning strategies that accommodate students coming from various regions in Indonesia, particularly to achieve equal competencies.

\begin{tabular}{|c|c|}
\hline \multicolumn{2}{|c|}{ TABLE II: THE CORE COMPETENCY AND THE INDICATORS } \\
\hline Core & Competency indicators \\
\hline \multicolumn{2}{|l|}{ Competency } \\
\hline Analyze the & Students can: \\
\hline $\begin{array}{l}\text { characteristics } \\
\text { of light, the }\end{array}$ & $\begin{array}{l}\text { Explain the reflection (image) formation on flat and } \\
\text { curved mirrors }\end{array}$ \\
\hline reflection & Calculate the number of reflections (images) \\
\hline (image) & formed by two angled mirrors \\
\hline
\end{tabular}

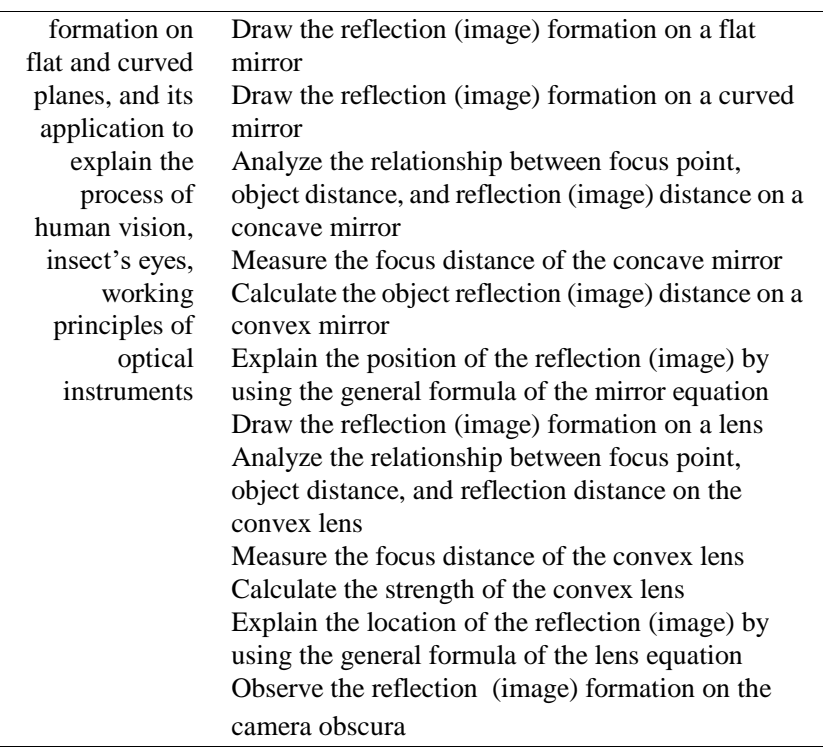

\section{B. Knowledge delivering strategy}

Materials are broken down into smaller learning units. Two factors determining the satisfaction level of online learning are the learning structure and interaction [8],[15]. In knowledge acquisition, students tend to be more comfortable in understanding materials when they are broken down into smaller sub-materials. Thus, the learning structure becomes more straightforward, does not need a long time duration of learning, and increases the student's learning satisfaction. In this research, reading materials were arranged in pdf format with the length of 2-3 pages, so students would not be tired of a long reading text. This way would ensure that the teaching present is done well. Learning material management is a form of teaching present that determines the student's learning success [7]. Besides giving several concepts and theories, the reading text also gave examples in daily life. By giving those examples, students could make a cognitive connection between theories and the daily phenomena, vice versa. Simple learning structure can increase student's learning satisfaction [8],[24]. In the reading text, the bigger size of and colorful fonts would emphasize the important concepts and theories. Fig. 2 shows the example of a screenshot of a part of habituation materials.

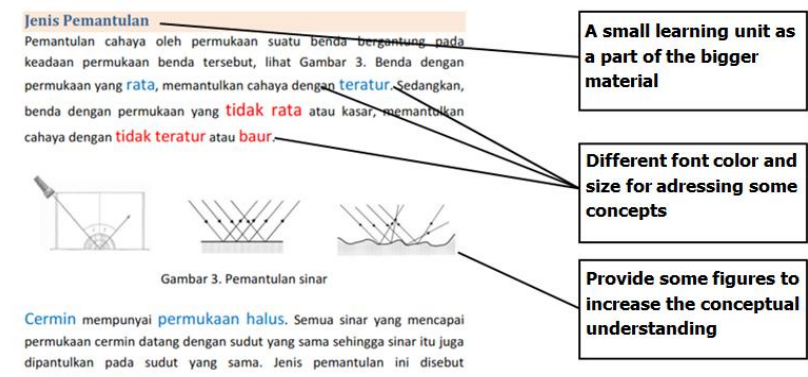

pantulkan pada sudut rang sume jenis parboga dipantulkan pada sudut yang sama. Jenis pemantulan ini disebu

Fig. 2. Content layout strategy

Asynchronous Interaction for Higher order thinking. Online activities used could be either synchronous or asynchronous. This activity management as designed structurally has influenced the student's positive perception level. This finding matches the similar research result [25]. The

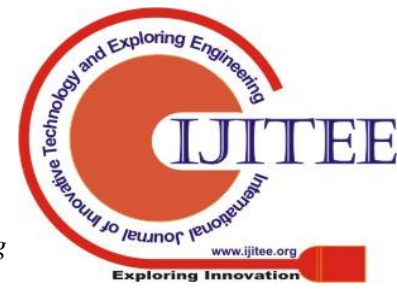


two activities were applied by using the feed/posting feature. Even though there is no specific guideline to be followed by the teacher to succeed in the online learning [10], one of the strategies to encourage higher order thinking skills is by developing critical thinking skill. This skill can be developed by giving questions that can develop thinking logically. In the opening activity of learning, the teacher delivered several questions from the daily cases. One thing to consider when delivering questions is that the teacher should not over-control the learning environment. The higher teacher's control in the learning environment will decrease the student's social presence and critical thinking [18]. The teacher's belief in interaction [3] and the roles played [19] via online influences the learning perception received by students. By using the posting menu on LMS, the teacher becomes the moderator of the student's discussion, so it encourages the various way of thinking alternatives. With this strategy, the teacher develops the feeling that students are socially connected with the teacher and the classmates [16]. In the activities, the teacher's role in ensuring that all students participate is essential. The participation level in the interactive communication process will determine online learning success [14]. This interaction is essential so that online communication interaction can represent the physical absence of the teacher. Several types of questions used as the trigger are such as "Why could this object be seen?" or "Why does the existence of light make the object seen?" From the learning process, by giving a trigger as a thread in the discussion, students become more enthusiastic in giving their opinions [17].

For this need, in every learning unit, the teachers in the team have prepared the various scenario and question database to trigger the students. Giving a trigger that makes students more enthusiastic in the learning interaction will increase the social presence intensity. This increase will encourage the increase of cognitive presence [12]. One thing to be noted is in this online learning, and the teacher has tried to avoid communication activities as the representative of social presence with informal and less-structured communication; like daily interaction and experience sharing [3]. This less-structured interaction can increase the student's satisfaction in online learning, and it automatically increases the learning success [8].

The interaction that encourages motivation and feedback. The intensity of the online communication between the teacher and students is essential; including how fast the teacher gives responses to the student's posts and the feedbacks. The fast response will tend to encourage student's motivation to interact again in another time. The absence of feedbacks will make students tend to fail in online learning [7],[17]. Thus, the strategies for encouraging communication and showing social presence determine the success of learning. Some other teachers assisted the principal teacher in this research in order that student's posts could be fast handled. Another strategy used was that the teacher avoided the right or wrong judgments on the student's opinions but re-question the students in another way so that critical thinking could develop.

This strategy matches the result of research stating that

some strategies to increase social presence are by giving highlight, emoticon, approval for student's comments, greetings, and mentioning names [7]. The primary key done by the teacher was by giving online appreciation on anything students do positively. In online learning, the teacher who gives respectful, timely, positive, frequent, and encouraging message can encourage the right social presence [20].

\section{Achievement Evaluation Strategy}

Achievement evaluation strategy used is by giving various types of evaluations such as true or false, statement matching, multiple choices, and essay questions. The test forms were provided with various difficulty levels. The varied types of questions make students not bored with finishing them. The questions were given at every end of sub-materials and at the end of particular materials (which is more comprehensive).

Beside questions to evaluate the level of competency achievement, in the online learning, anonymous polling was also provided to find out the comprehension level of all students. By using this polling, the teacher could determine appropriate strategies to ensure that all students achieve the competencies. The polling could be given to students after reading the materials. The result of the polling became the basis in giving trigger questions that develop logical and critical thinking.

\section{Menu in the Edmodo}

Based on the materials delivery strategy and learning achievement evaluation strategy used, in every learning activity for particular materials, there would be several learning cycles for sub-materials learning. Generally, the cycles include apperception, polling to check the prior knowledge, providing reading resources, directed discussion, quiz, feedback and appreciation, and overall evaluation. Table III shows the relationship between the activities on the cycles and features on the menu in the Edmodo.

The teacher was given a learning manual that provides guidelines for learning activities. The contents of this manual include examples of subject matter, how to do an aperspion, how to provide learning feedback, how to motivate students, quizzes, and assignments. In the implementation of learning, the teacher was allowed to make modifications from existing ones that were tailored to the learning situation. In this way learning became more flexible and in accordance with the context.

\begin{tabular}{|c|c|c|c|}
\hline No & Activities & Menu & Type \\
\hline 1 & Apperception & Posting & Text \\
\hline 2 & $\begin{array}{l}\text { Measuring prior } \\
\text { knowledge }\end{array}$ & Polling & Multiple Choice \\
\hline 3 & $\begin{array}{l}\text { Providing reading } \\
\text { resources }\end{array}$ & Posting & Attachment (pdf), Link \\
\hline 4 & Directed discussion & Posting & Text \\
\hline 5 & $\begin{array}{l}\text { Measuring reading } \\
\text { materials comprehension }\end{array}$ & Quiz & $\begin{array}{c}\text { T/ F, Matching, } \\
\text { Multiple choices, Essay }\end{array}$ \\
\hline 6 & Feedback and & Posting & Text \\
\hline 7 & overall evaluation & Quiz & $\begin{array}{l}\text { T/ F, Matching, multiple } \\
\text { choices, Essay, Essay }\end{array}$ \\
\hline
\end{tabular}


By using the menu in Edmodo, the teacher carries out learning as planned. The important thing in this learning is to maintain student motivation through social presence during the learning process. Fig. 3 to Fig. 5 show some screenshots of the activities.

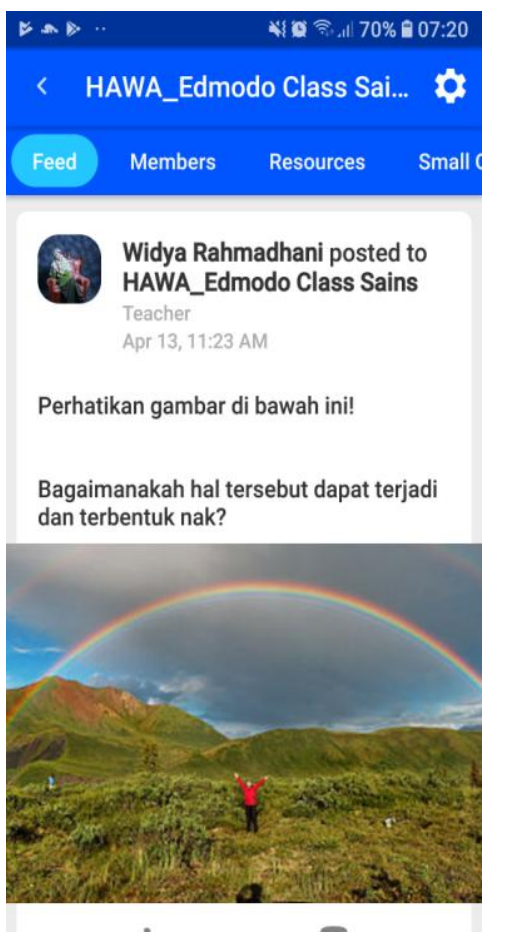

Fig. 3. Screenshot of some activities: Students discussion on physics phenomena. Students explain their opinion on 'what is light.' It is just remembering or understanding level.

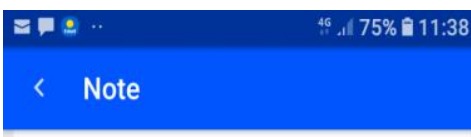

Amanda Laila 12 minutes ago Cahaya adalah energi berbentuk gelombang elektromagnetik yang kasat mata dengan panjan gelombang sekitar $380-750 \mathrm{~nm}$.

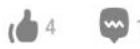

View 1 reply to this comment..

(3)

Zia Ferdian Anwar 12 minutes ago Cahaya adalah sebuah sinar, yang datang dari berbagai sumber

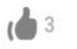

View 1 reply to this comment..

Alief Cahya

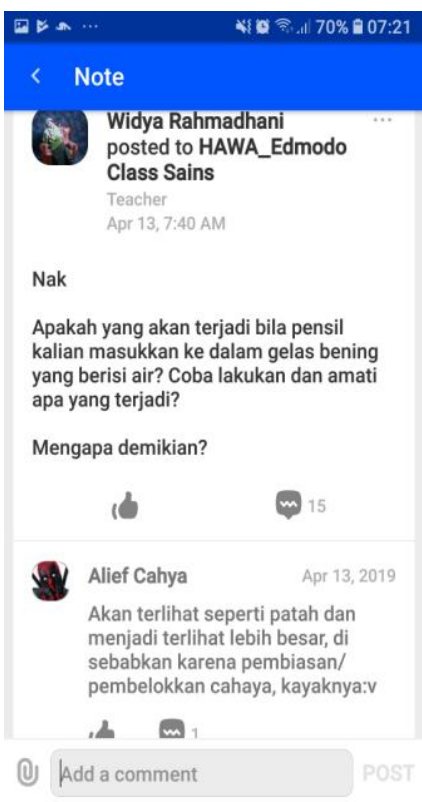

Fig. 5. Screenshot of some activities: A discussion on bending of light on an object. The student showed their critical thinking to explain the causal-effect of the phenomena

\section{E. Student Response}

This learning program with Edmodo was carried out within three meeting days (@ 3 hours per day). This strategy implementation is suitable if carried out continuously on the same day. In this way, students who had entered a conducive learning environment would not be cut off due to time constraints. After learning, students filled out the USE questionnaire. The response to learning with mobile learning conducted on 33 of eighth-grade students is shown in Table IV.

TABLE IV: THE SUMMARY OF THE STUDENT'S RESPONSE

\begin{tabular}{|c|c|c|c|c|c|}
\hline CODE & Criteria and items & $\mathbf{S A}$ & $\mathbf{A}$ & D & SD \\
\hline & Usefulness & & & & \\
\hline US1 & It helps me be more effective. & 8 & 25 & 0 & 0 \\
\hline US2 & It helps me be more productive. & 7 & 25 & 1 & 0 \\
\hline US3 & It is useful. & 13 & 20 & 0 & 0 \\
\hline US4 & $\begin{array}{l}\text { It gives me more control over the } \\
\text { activities in my life. }\end{array}$ & 6 & 26 & 1 & 0 \\
\hline \multirow[t]{2}{*}{ US5 } & $\begin{array}{l}\text { It makes the things I want to } \\
\text { accomplish easier to get done. }\end{array}$ & 8 & 23 & 2 & 0 \\
\hline & Easy to Use & & & & \\
\hline EU1 & It is easy to use. & 6 & 23 & 4 & 0 \\
\hline EU2 & It is simple to use. & 7 & 26 & 0 & 0 \\
\hline EU3 & It is user-friendly. & 7 & 22 & 4 & 0 \\
\hline EU4 & $\begin{array}{l}\text { It requires the fewest steps possible } \\
\text { to accomplish what I want to do } \\
\text { with it. }\end{array}$ & 9 & 21 & 3 & 0 \\
\hline \multirow[t]{2}{*}{ EU5 } & $\begin{array}{l}\text { I can use it without written } \\
\text { instructions. }\end{array}$ & 6 & 25 & 2 & 0 \\
\hline & Easy to learning & & & & \\
\hline EL1 & I learned to use it quickly. & 8 & 21 & 4 & 0 \\
\hline EL2 & I easily remember how to use it. & 10 & 18 & 5 & 0 \\
\hline EL3 & It is easy to learn to use it. & 7 & 20 & 6 & 0 \\
\hline \multirow[t]{2}{*}{ EL4 } & I quickly became skillful with it. & 10 & 16 & 7 & 0 \\
\hline & Satisfaction & & & & \\
\hline SA1 & I am satisfied with it. & 9 & 19 & 5 & 0 \\
\hline SA2 & I would recommend it to a friend. & 5 & 25 & 3 & 0 \\
\hline SA3 & It is fun to use. & 9 & 21 & 3 & 0 \\
\hline SA4 & It works the way I want it to work. & 8 & 20 & 5 & 0 \\
\hline SA5 & It is pleasant to use. & 10 & 23 & 0 & 0 \\
\hline
\end{tabular}


The percentage of each statement category can be figured out by the following Fig. 6 to Fig. 9. Using this figure, we can analyze more detail on the student's response. The analysis was done in aggregate by comparing the percentage of respondents who stated strongly disagree $(\mathrm{SD})$ and disagree (D) with those who agree (A) and strongly agree (SA). The trend towards the results of these two groups is the basis for deciding the quality of learning developed.

On Usefulness criteria (Fig. 6), some students stated disagree on three items (US2, US4, and US5) with a low average $(2.4 \%)$. This result means that $97.6 \%$ of students feel that learning with Edmodo is beneficial for them. Some possibilities are caused by students feeling that mobile learning lacks benefits can be traced to the level of interaction between teachers and students who need to be more social side presence. Giving appreciation to students during this study has not been intensive enough.

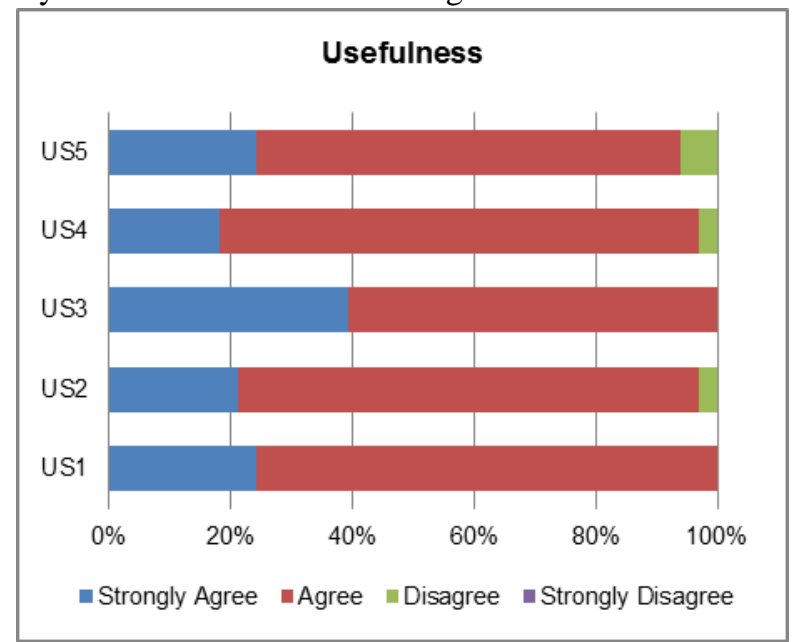

Fig. 6. The percentage of each item of usefulness criteria

On the criteria for Ease to Use (Fig. 7), only in EU2 that there were no students who stated disagree. In other items, some students were Disagree (7.9\% on average) with ease of learning with this LMS. Observations on the conduct of studies, students in this school on a typical day are prohibited from using or carrying a smartphone at school. This prohibition becomes a possible cause that students feel new in using the application. As a result, not all students find it easy to use the app.

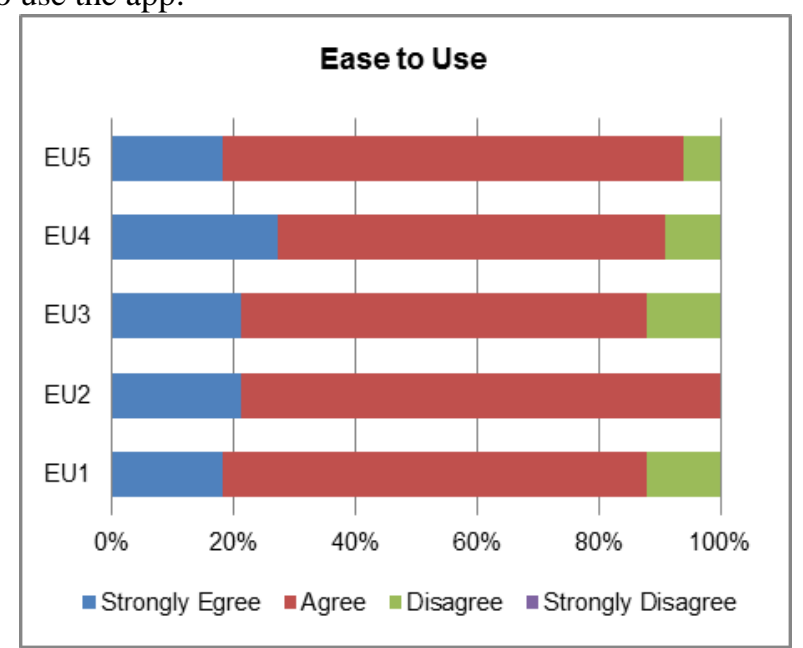

Fig. 7. The percentage of each item of ease to use criteria
On the Ease to Learning criteria (Fig. 8), some students declare to Disagree on all items (16.7\% on average). This percentage is the highest among the other criteria. Criteria for Ease to Use and Ease to Learning are criteria that are very closely related. This high percentage needs to find a solution so that no one fails in learning. Searching for the level of success of students in working on the questions related to the material, students who stated Disagree did not experience learning failure (high learning achievement scores). Possible causes are the teacher's ability to build online interactions or on student learning styles. Student learning styles in this study are a limitation because they are not used as the factors studied.

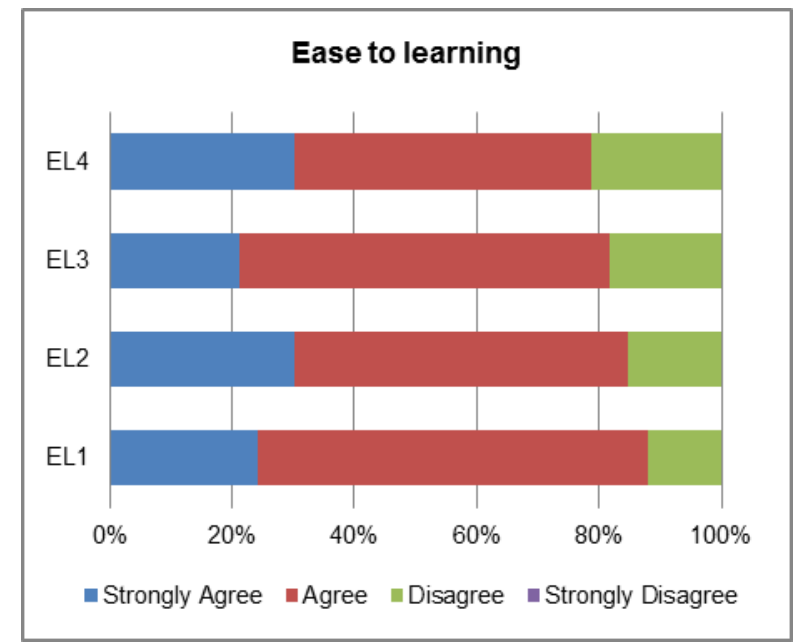

Fig. 8. The percentage of each item of ease to learning criteria

On the Satisfaction criteria (Fig. 9), some students declare Disagree in all items (except SA5) with a relatively low average percentage $(9.7 \%)$. These results imply that students as a whole feel satisfied with the application used and the learning activities carried out. Observation of aspects that still disagree can be identified that this learning method is new at school.

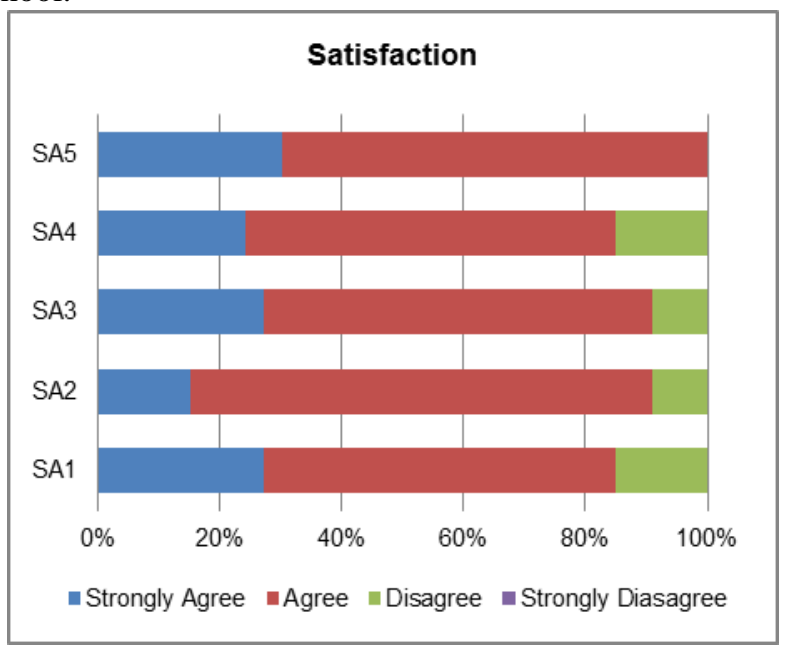

Fig. 9. The percentage of each item of satisfaction criteria

Overall criteria show that LMS and learning activities carried out can meet student learning needs well $(89.8 \%$ stated SA or A). These results provide optimism that mobile learning with appropriate strategies can meet the learning needs of science, 
including in schools that have never used this technology before.

\section{Conclusion}

In online learning, the level of social presence needs to be designed to ensure the learning success and the student's learning competencies achievement. To decrease the level of student's boredom in learning materials, the teacher can apply the strategy of breaking down materials into smaller sub-materials. The teacher's capability in managing learning that motivates students can be done by giving challenging questions related to daily phenomena and communicating less-formally following the student's psychological development. To evaluate the learning material comprehension, the teacher can provide various types of questions as a strategy to create online learning comfort. With those learning strategies, students generally think this design is excellent on the aspects of usefulness, easy to use, easy to learn, and satisfaction.

\section{REFERENCES}

\section{(Periodical style)}

1. J. G. S. Goldie, "Connectivism: A knowledge learning theory for the digital age?" Medical teacher, vol. 38, no. 10, pp. 1064-1069, 2016.

2. C. H. Tu, "On-line learning migration: from social learning theory to social presence theory in a CMC environment," Journal of network and computer applications, vol. 23, no. 1, pp. 27-37, 2000.

3. J. C. Richardson, E. Besser, A. Koehler, J. Lim, and M. \& Strait, "Instructors' perceptions of instructor presence in online learning environments," The International Review of Research in Open and Distributed Learning, vol 17, no. 4, pp. 82-103, 2016.

4. D. Sulisworo, D. A. Kusumaningtyas, E. Nursulistiyo, and T Handayani, "Mobile learning infusion through enhancing teachers' perception: Case study in eastern of Indonesia," In International Conference on Science, Technology, Education, Arts, Culture and Humanity-" Interdisciplinary Challenges for Humanity Education in Digital Era"(STEACH 2018), (pp. 85-88). Atlantis Press, 2019.

5. I. Kožuh, Z. Jeremić, A. Sarjaš, J. L. Bele, V. Devedžić, and M. Debevc, "Social presence and interaction in learning environments: The effect on student success," Journal of Educational Technology \& Society, vol. 18, no. 1, pp. 223-236, 2015.

6. O. Poquet, V. Kovanović, P. de Vries, T. Hennis, S. Joksimović, D. Gašević, and S. Dawson, "Social presence in massive open online courses," International Review of Research in Open and Distributed Learning, vol. 19, no. 3, pp. 43-68, 2018.

7. J. C. Richardson, A. A. Koehler, E. D. Besser, S. Caskurlu, J. Lim, and C. M. Mueller, "Conceptualizing and investigating instructor presence in online learning environments," The International Review of Research in Open and Distributed Learning, vol. 16, no. 3, pp. 256-297, 2015

8. M. B. Horzum, "Interaction, Structure, Social Presence, and Satisfaction in Online Learning," Eurasia Journal of Mathematics, Science \& Technology Education, vol. 11, no. 3, pp. 505-512, 2015.

9. J. Richardson, K. Swan, P. Lowenthal, and P. Ice, "Social presence in online learning: Past, present, and future," In Global Learn (pp. 477-483). Association for the Advancement of Computing in Education (AACE), April 2016.

10. J. Yuan, and C. Kim, "Guidelines for facilitating the development of learning communities in online courses," Journal of Computer Assisted Learning, vol. 30, no. 3, pp. 220-232, 2014.

11. Y. Mor, R. Ferguson, and B. Wasson, "Learning design, teacher inquiry into student learning and learning analytics: A call for action," British Journal of Educational Technology, vol. 46, no. 2, pp. 221-229, 2015

12. S. M. Lee, "The relationships between higher order thinking skills, cognitive density, and social presence in online learning," The Internet and Higher Education, vol. 21, pp. 41-52, 2014.

13. S. Joksimović, D. Gašević, V. Kovanović, B. E. Riecke, and M. Hatala, "Social presence in online discussions as a process predictor of academic performance," Journal of Computer Assisted Learning, vol. 31, no. 6, pp. 638-654, 2015.
14. J. Bowers, and P. Kumar, "Students' perceptions of teaching and social presence: A comparative analysis of face-to-face and online learning environments," International Journal of Web-Based Learning and Teaching Technologies (IJWLTT), vol. 10, no. 1, pp. 27-44, 2015.

15. M. T. Cole, D. J. Shelley, and L. B. Swartz, "Online instruction, e-learning, and student satisfaction: A three year study," The International Review of Research in Open and Distributed Learning, vol. 15, no. 6, pp. 111-131, 2014.

16. J. A. Gray, and M. DiLoreto, "The effects of student engagement, student satisfaction, and perceived learning in online learning environments," International Journal of Educational Leadership Preparation, vol. 11, no. 1, pp. 1-20, 2016.

17. J. C. Dunlap, and P. R. Lowenthal, "The power of presence: Our quest for the right mix of social presence in online courses," In Real life distance education: Case studies in practice, 41-66, Information Age Publishing, 2014.

18. J. Costley, "The effects of instructor control on critical thinking and social presence: Variations within three online asynchronous learning environments," Journal of Educators Online, vol. 13, no. 1, pp. 109-171, 2016.

19. J. Ma, X. Han, J. Yang, and J. Cheng, "Examining the necessary condition for engagement in an online learning environment based on learning analytics approach: The role of the instructor," The Internet and Higher Education, vol. 24, pp. 26-34, 2015.

20. K. Plante, and M. E. Asselin, "Best practices for creating social presence and caring behaviors online," Nursing Education Perspectives, vol. 35, no. 4, pp. 219-223, 2014

21. D. Sulisworo, L. Yunita, and A. Komalasari, "Which Mobile Learning is More Suitable on Physics Learning in Indonesian High School?" International Journal of Recent Contributions from Engineering, Science \& IT (iJES), vol. 5, no. 1, pp. 97-104, 2017.

22. D. Sulisworo, and K. Permprayoon, "What is the Better Social Media for Mathematics Learning? A Case Study at A Rural School in Yogyakarta, Indonesia," International Journal on Emerging Mathematics Education, vol. 2, no. 1, pp. 39-48, 2018.

23. A. M. Lund, "Measuring usability with the use questionnaire," Usability interface, vol. 8, no. 2, pp. 3-6, 2001.

24. R. A. Croxton, "The role of interactivity in student satisfaction and persistence in online learning," Journal of Online Learning and Teaching, vol. 10, no. 2, pp. 314-324, 2014.

25. L. C. Yamagata-Lynch, "Blending online asynchronous and synchronous learning," The International Review of Research in Open and Distributed Learning, vol. 15, no. 2, pp. 189-212, 2014.

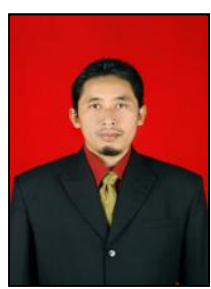

\section{AUTHORS PROFILE}

Dwi Sulisworo is Professor in Educational Technology. His Doctorate is from Malang State University, Indonesia. He is scholar in Physics Education Department, Graduate Program, Ahmad Dahlan University, Indonesia. He has published many papers in the reputable international journals and proceedings. Email: sulisworo@gmail.com

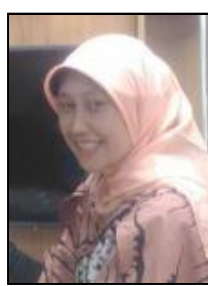

Dian Artha Kusumaningtyas is faculty member in Physics Education Department, Undergraduate Program, Ahmad Dahlan University, Indonesia. She is pursuing doctorate degree in Education Evaluation in Yogyakarta State University. Now, her position is as the Head of Educators and Education's Staff Development Institute of Ahmad Dahlan University. Email:dian_uad@yahoo.com

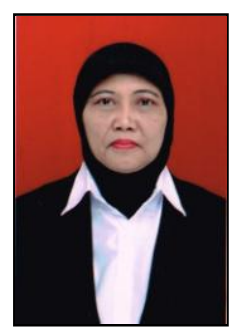

Trikinasih Handayani is Assoc. Professor in Biology Education. Her doctorate degree is from Yogyakarta State University, Indonesia. She is Dean of Education and Teacher Training Faculty of Ahmad Dahlan University. Email: trikinasih@pbio.uad.ac.id 
The Learning Design And Student's Response To Physics Online Learning In Rural School Of Indonesia

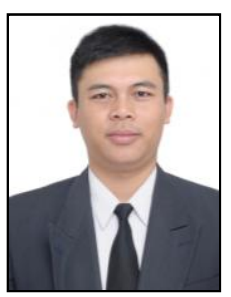

Eko Nursulistiyo is faculty member in Physics Education Department, Undergraduate Program, Ahmad Dahlan University, Indonesia. His master degree is from Yogyakarta State University. He has expertise on the learning strategy development, technology enhance learning especially on physics. Now, he is the Head of Physics Education Department of Ahmad Dahlan University. Email: ekonur.uad@gmail.com 